\section{Dinucleotide repeat polymorphism at the human GLUT2 locus}

\author{
P.Patel1, 2, Y.M.D.Lo', G.I.Bell, R.C.Turner ${ }^{2}$ and \\ J.S.Wainscoat ${ }^{1}$, * \\ 'Department of Haematology, John Radcliffe Hospital, \\ Headington, Oxford OX3 9DU, ${ }^{2}$ Diabetes Research \\ Laboratories, Nuffield Department of Clinical Medicine, \\ Radcliffe Infirmary, Oxford, UK and ${ }^{3}$ Howard Hughes \\ Medical Institute, University of Chicago, 5841 S. Maryland \\ Avenue, Box 391, Chicago, IL 60637, USA
}

Source and Description: A (dC-dA)n . (dG-dT)n sequence was found within an intron of the human liver/islet glucose transporter (GLUT2) gene. Two oligonucleotides homologous to the sequences flanking the dinucleotide repeat were used to amplify the region and generate a fragment of the predicted size of $112 \mathrm{bp}$.

Primer Sequences:

5' CTCCAAGAAGCATATCAGGA 3' (CA strand)

5'GTCCACATACCGCCTTTAGAG 3'(GT strand)

Frequencies: Estimated from 44 chromosomes of unrelated Caucasian family parents.

$\begin{array}{llll}\text { Allele (bp) } & \text { Frequency } & \text { Allele (bp) } & \text { Frequency } \\ \text { K1 } 124 & 0.05 & \text { K3 } 120 & 0.54 \\ \text { K2 } 122 & 0.23 & \text { K4 } 116 & 0.18\end{array}$

Chromosomal Localization: Assigned to chromosome $3 q 26.1-3 q 26.3$ using a panel of mouse-human somatic cell hybrids and by in situ hybridisation to metaphase chromosomes (1).

Mendelian Inheritance: Co-dominant segregation observed in two Caucasian families (38 individuals).

Other Comments: The PCR reaction was performed on $1 \mu \mathrm{g}$ genomic DNA as previously described (2) except that samples were processed through 30 temperature cycles consisting of 2 min at $94^{\circ} \mathrm{C}, 2 \mathrm{~min}$ at $55^{\circ} \mathrm{C}$ and $3 \mathrm{~min}$ at $72^{\circ} \mathrm{C}$. PCR products were fractionated on $10 \%$ PAGE gel and visualized by staining with ethidium bromide. The sizes of the alleles were determined by comparision with $M s p I$ digested $p B R 322$ DNA. The sequence of GLUT2 can be obtained from Dr.G.I. Bell.

Acknowledgements: This work was supported by a grant from the Medical Research Council (U.K.).

References: 1) Fukumoto,H. et al. (1988) Proc. Natl. Acad. Sci. USA 85, 5434-5438. 2) Saiki,R.K. et al. (1988) Science 230, $487-491$.

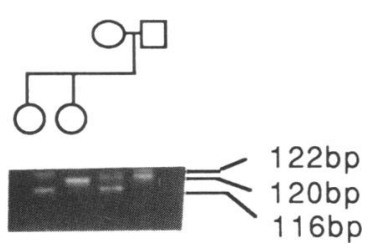

* To whom correspondence should be addressed

\section{Smal and Hhal polymorphisms in the $5^{\prime}$ region of the human von Willebrand factor gene (F8VWF)}

L.Strain, D.T.Bonthron and D.J.H.Brock

Human Genetics Unit, University of Edinburgh, Western

General Hospital, Crewe Road, Edinburgh, EH4 2XU, UK

Description: Comparison of genomic DNA sequences (1) predicted three polymorphisms, SmaI, HhaI and BspHI within a $1.46 \mathrm{~kb}$ amplified segment of the human vWF gene spanning exon 3 .

Primer Sequences:

5' AGG TAG TTT GCA CAA GTT GGT CAC 3'

5' CAA CCT TCA TGA GCC TTG GTT CTC 3'

Methods: PCR conditions: $10 \mathrm{mM}$ Tris- $\mathrm{HCl}$ pH 8.3, $50 \mathrm{mM} \mathrm{KCl}$, $1.5 \mathrm{mM} \mathrm{MgCl} 2,0.5 \mu \mathrm{M}$ primers, $200 \mu \mathrm{M} \mathrm{dNTP}, 0.5 \mu \mathrm{g} \mathrm{DNA}$, $10 \%$ DMSO and $1 \mathrm{U}$ Taq polymerase to $100 \mu \mathrm{l}$. 36 cycles: $94^{\circ} \mathrm{C}$ ( $1 \mathrm{~min}), 65^{\circ} \mathrm{C}(2 \mathrm{mins})$ and $72^{\circ} \mathrm{C}(1.5 \mathrm{mins})$.

SmaI Polymorphism: Position 4996 (1).

Allele Q1: 1109 bp; Q2: 857, 252 bp. Constant band; 352 bp.

HhaI Polymorphism: Position 5195 (1).

Allele R1: 1156 bp; R2: 1010, 146 bp. Constant band; 305 bp.

BspHI Polymorphism: Position 5971 (1).

No BspHI site detected in 80 chromosomes analysed.

Allele Frequencies: (176 chromosomes examined).

Q1 and R1 show complete linkage disequilibrium; frequencies at both SmaI and HhaI sites are allele 1: 0.34; allele 2: 0.66 . Polymorphism Information Content $=0.35$

In heterozygotes double digestion confirmed that Q1 and R1 lay on the same chromosome. No Q1,R2 or Q2,R1 haplotypes were observed.

Mendelian Inheritance: Co-dominant segregation was demonstrated in 26 meioses in 2 families.

Chromosomal Localization: 12p12-12pter (2).

Acknowledgements: This research was supported by the Ludovici Bequest Fund to the University of Edinburgh.

References: 1) Mancuso,D.J., Tuley,E.A., Westfield,L.A., Worrall,N.K., Shelton-Inloes,B.B., Sorace,J.M., Alevy,Y.G. and Sadler,J.E. (1989) J. Biol. Chem. 264, 19514-19527. 2) Ginsburg,D., Handin,R.I., Bonthron,D.T., Donlon,T.A., Bruns,G.A.P., Latt,S.A. and Orkin,S.H. (1985) Science 228, $1401-1406$.

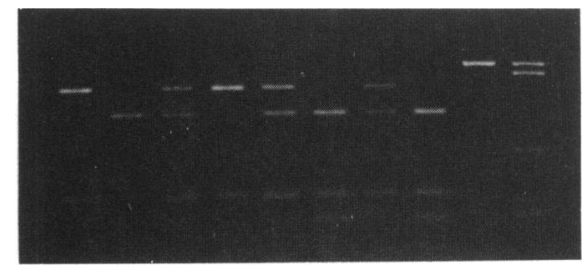

Figure 1. 1.4\% agarose gel showing SmaI digestion products (undigested product - lane 9). Marker (10) is TaqI digested pBR322. 